\author{
Sh. Seilov ${ }^{1}$, V. Goykhman ${ }^{2}$, M. Kassenova ${ }^{1}$, A. Seilov ${ }^{1}$, D. Shingissov ${ }^{1}$ \\ ${ }^{1}$ L.N. Gumilyov Eurasian National University, Nur-Sultan, Kazakhstan; \\ ${ }^{2}$ LLC Scientific and Technical Center «SOTSBI», Saint Petersburg, Russia \\ (E-mail: seilov@kai.kz)
}

\title{
Development of neural network models for the analysis of infocommunication traffic
}

\begin{abstract}
This article discusses the problems of today's infocommunication networks, the basis of which are multiservice networks serving all types of traffic, presented as a set of IP packets. The characteristic features of this traffic are analyzed, each of which is oriented to a certain class of services. The knowledge gained as a result of ongoing traffic research is an essential factor for increasing the effectiveness of decisions made in various fields of the telecommunications industry. The need for knowledge of the nature of traffic circulating in the network and the laws of its behavior is revealed and substantiated. Without this, it is impossible to effectively manage networks, develop solutions for their development, ensure network security and maintain the required level of quality. Despite the large number of works about building multi-service networks, a number of issues require further study. Analysis of traffic studies of modern converged, multiservice networks showed the lack of knowledge about its nature and laws of behavior, given the high variability of its characteristics. Thus, it can be argued that the parameters of the studied traffic are statistical, probabilistic in nature, can vary randomly over time and, accordingly, based on the study, the author proposes a study using statistical analysis methods. To study traffic, you should use the tools of probability theory and mathematical statistics.
\end{abstract}

Keywords: infocommunication networks, neural networks, multiservice traffic, probabilistic traffic characteristics, mathematical traffic models, multimedia services, multiservice traffic, neural network technologies, studied distributions, traffic classifications, information objects.

\section{Introduction}

Artificial neural networks being, although very primitive, but still, being an analog of the principles of the human brain are used to solve those problems that are unknown how to solve. To solve these problems, there is no finite or approximate solution algorithm that can be expressed by an equation or a block diagram. These, in particular, include recognition and recognition of speech and images, as well as complex forecasting tasks carried out with a limited set of known input data, analysis of big data, i.e. such tasks that are solved by a person «unconsciously». Such tasks include the tasks of studying telecommunications traffic.

Previous studies in [1-3] confirmed the earlier hypothesis about the stability of the distributions of the probability characteristics of traffic generated by typical information objects, such as student campuses, office centers, sports and entertainment facilities, etc.

Since the traffic of these objects is, in the probabilistic sense, stable in nature, its characteristic features can be described by certain models that can be used in the construction and development of communication networks focused on specific typical traffic sources.

Thus, there is reason to believe that network traffic generated by various information objects will have distinctive features of the probability distributions of the corresponding traffic characteristics. Accordingly, as one of the directions of the study of infocommunication traffic, one should single out the classification of the probability distributions of its characteristics.

\section{The use of neural networks for the analysis of infocommunication traffic}

An analytical review of modern scientific and technical literature in the field of infocommunications showed that the most widespread in works devoted to traffic approximation, approximation of observed distributions, as well as the construction of mathematical traffic models, were such types of distributions as: Poisson distribution, normal distribution, Weibull distribution, Pareto distribution and hyperexpo-nential distribution. 
In multiservice networks, mathematical models of traffic flows from the simplest Poisson to the complex model of fractal processes can be used.

The advent of pervasive sensor networks, the Internet of things, NGN networks, and other technologies complicates the dynamic processes that occur in information and communication networks. Multimedia services (video streaming, interactive games, etc.) are gaining more and more popularity as compared to classical communication services.

Three main types of traffic can be distinguished [4]:

1. Homogeneous traffic in monoservice networks. Representatives of this type are telephone networks that provide only voice communication services; in most cases, this traffic corresponds to an elementary Poisson stream model. This model has been widely used in information distribution systems such as switched telephone networks. The description of flow models in classical telephone networks was mainly carried out on the basis of an ordinary flow without aftereffect, obeying the family of Poisson distributions [5]. The widespread use of the Poisson stream is due, in particular, to one of its essential properties - the additivity property - the sum of Poisson flows is also a Poisson stream.

2. Heterogeneous traffic in multiservice networks. The nature of this traffic is determined by the wide range of services provided and the integrated characteristics of the multiservice network. This type of traffic is characterized by increased unevenness.

3. Multiservice traffic in packet networks. Traffic of this type is heterogeneous and even more different from the Poisson stream. A single network is used to transmit streams of various services, but traffic sources differ in data transfer speed, type of traffic generation and transmission. Such flows are characterized by «burstiness», which causes even greater traffic unevenness.

Thus, packet switched multiservice networks traffic is already significantly different from Poisson stream. Multiservice traffic has non-stationary properties and is described by heavy-tailed distributions. Such type of distributions, including the phenomenon of long-term dependence, are signs a large number of popular IP applications correspond to slowly decaying distributions, for example, some studies show that VoIP is characterized by Pareto distribution, FTP / TCP traffic is characterized by Weibull distribution or lognormal distribution, and HTTP / TCP is characterized by lognormal distribution or Pareto distribution [6].

The Weibull and Pareto distributions are examples of slowly decreasing dependencies. Due to the large dispersion value, these distributions are characterized by certain computational difficulties, because of the need to consider large amounts of static information [7].

As you know, classification issues are effectively addressed using neural network technologies. Consider the possibility of using neural networks to classify the main typical probability distributions.

The analysis of neural network models determined the choice for further studies of a multilayer network with direct signal propagation.

There are various software tools for implementing neural networks: Matlab, Python, RStudio, $\mathrm{C}++$, etc. At the previous stage of the study, the Matlab software package was chosen as a tool for working with neural networks [8-10]. It provides a convenient graphical interface and contains most of the necessary built-in functions, however, experience with the package showed its lack of speed with an increase in the amount of input training effects. Therefore, the programming language Python was chosen as a platform for implementing a neural network.

Python provides the ability to select a neural network model, flexible parameter settings, as well as various implementation options for activation functions and learning algorithms. The disadvantage of this toolkit is the lack of a graphical interface. Another advantage of the Python programming language is the availability of various libraries for modeling neural networks $[11,12]$.

In this work, the PyBrain library is selected as the Python library for performing operations with neural networks. PyBrian is a modular library designed to implement various machine learning algorithms in Python.

To initialize a neural network in PyBrain, the net = buildNetwork (layers, options) function is used. This function creates a network consisting of the number of layers and neurons in them required by the developer. The layers argument indicates the number of neurons in the layer, and enumerating multiple values with a comma specifies the number of layers. The options argument is a variety of options that you can configure when creating a neural network. For example, you can set your own activation function for the output and for each of the hidden layers.

The training set for a neural network is set by the function ds = SupervisedDataSet (inp, target). The inp parameter is responsible for the data that will be input to the neural network. The target parameter is the target neural network training vector, i.e., the vector of those values that the neural network should produce 
for a given set of input values. The advantage of the PyBrain library is the ability to create data for training a neural network using both the Python programming language and load previously created values from a file.

The neural network learning algorithm is defined by the function corresponding to the name of the algorithm. In this paper, we study the training of a neural network using the error back propagation algorithm, and it is specified in this environment by the function trainer = BackpropTrainer (net, ds). The net argument is a link to the network in the form of the previously declared network name, which must be trained using this algorithm.

The neural network training is initialized using the trainer.train function, where the trainer is a link to the previously specified training algorithm. Calling the train method performs one iteration (era) of training and returns the value of the quadratic error. In order not to organize a cycle for passing through each era, there is a training network function for convergence - trainer.train Until Convergence (ds, maxEpochs). The ds argument indicates which data to use as the training set. The maxEpochs argument allows you to limit the number of iterations during which the neural network will be trained. Regulation of this argument reduces the training time of the neural network. If continuing training using initial vectors will worsen the approach to verification vectors, then network training will stop earlier. The functional toolkit of the PyBrain library also allows you to set the value of the target learning error and control the learning speed.

After the training of the neural network is completed, you can begin to test it. To test a neural network, you must use the previously described function SupervisedDataSet (inp, target) to specify the data that must be supplied to the input of the neural network, as well as the values of the target vector that should be obtained at the output. If the target vector for the test data is not known, it must be filled with zeros by default. Similar to the training sequence, you can create data for testing a neural network using the Python programming language or load previously created values from a file.

Neural network testing is initialized using the trainer.testOnClassData (ds) function. The ds parameter in this function indicates the data set on which to test. If this parameter is not specified, then by default testing is performed on the data used in training the neural network.

\section{Building a neural network architecture}

The problem of traffic classification that we are solving consists in assigning the investigated real traffic to one of the known probability distributions. To do this, you need to create a neural network that can identify the correspondence between the parameters of the input data and the known probability distributions, i.e. with a given certainty will ensure the formation of the output signal corresponding to a certain distribution law.

Let us turn to the traffic statistics of one of the typical information objects, on the basis of which there was a selection of parameters for study [10]. His analysis showed a significant predominance of TCP traffic. Therefore, at this stage, for further research, the following parameter was selected that characterizes TCP traffic - the duration of TCP sessions. It is also interesting because it to some extent represents an analogue of the duration of connections of traditional telephone networks, which provides the basis for future comparative analysis. The statistics used in this work contained information about TCP sessions, the overwhelming number of which did not exceed 3000s in duration.

It is known that to select the architecture of a neural network, it is necessary to determine the number of hidden layers and the number of neurons in each layer, the size of the input and output vectors, and in addition, select the activation function. A vector, in accordance with the terminology adopted in neural networks, is understood as a set of data supplied to or received from the input of a neural network.

The studied traffic mainly contained TCP sessions, the duration interval of which ranged from 0 to $3000 \mathrm{~s}$. At this stage of the study, this interval [0: 3000] was divided into uniform segments with a step of 60, which allowed the formation of samples containing 51 values (one from each segment). As a result, it was assumed that the dimension of the input layer of the neural network contains 51 neurons.

An assumption was made that all considered samples have the same values of mathematical expectation and variance, corresponding to the nature of the TCP sessions of the analyzed traffic approximated by ideal distributions. The values of each distribution determine the number of TCP sessions from 0 to $3000 \mathrm{~s}$ in length, provided that they are approximated by these distributions. Therefore, 51 values of each of the studied distributions, which will form the input vector, should be fed to the input of the neural network. In fig. Figure 1 shows graphs of the studied distributions. 


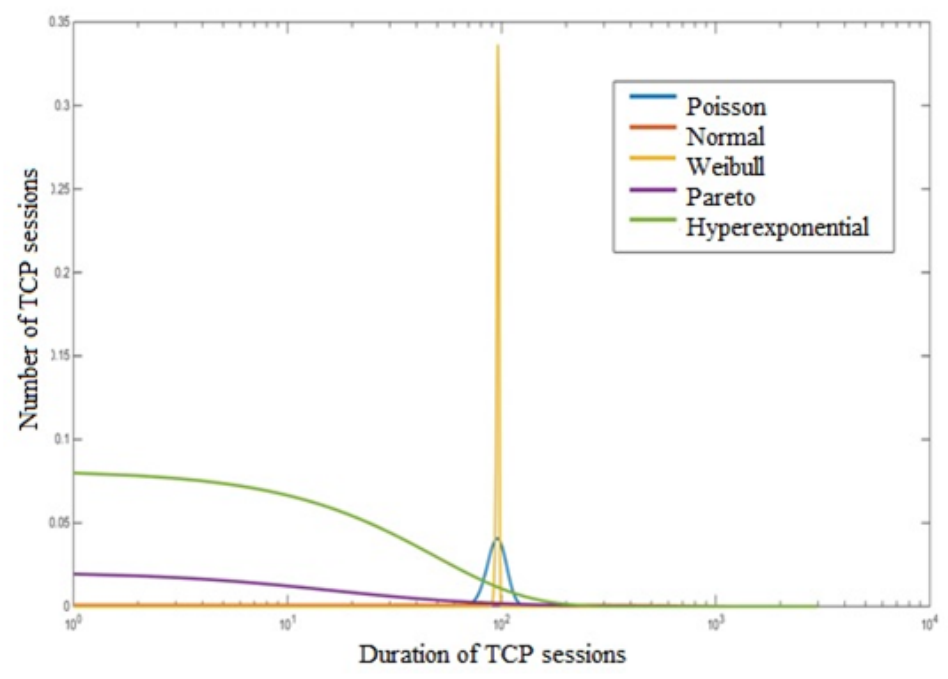

Figure 1. Graphs of the studied distributions

The output of a neural network determines which of the five commonly used distributions the input data have the most correspondence, based on which five neurons were involved in the output layer. Each of the neurons of the last layer is associated with an output that «encodes» the distribution. The assignment of the input sample to the corresponding distribution law is performed with the initially specified reliability. To verify the effectiveness of the proposed neural network architecture and search for an acceptable design option, the number of hidden layers and the number of neurons in them were changed [13, 14].

During testing, 100 experiments were conducted for each of the distributions. By one experiment is meant the input of a trained neural network (with a certain number of neurons and hidden layers, as well as with a given volume of the training sample) of the input sample corresponding to one of the known distributions and not included in the training sample. The result of each experiment was the value of the output vector, with a given reliability, showing the distribution law, which corresponded to the sample submitted to the input of the neural network. According to the results of all experiments, the proportion of successfully (correctly) recognized distribution laws was determined according to the success criterion (Tables 1 and 2). The proportion of correctly recognized distribution laws was estimated by assigning the resulting sum of successes to the total number of experiments.

The number of input samples successfully recognized by the neural network, \%

\begin{tabular}{|c|c|c|c|c|c|c|c|c|}
\hline & \multicolumn{7}{|c|}{ Number of hidden layers } \\
\hline & & & & 1 & & 2 & 3 & 4 \\
\hline & & \multicolumn{7}{|c|}{ The number of neurons in the hidden layer } \\
\hline \multirow[t]{2}{*}{1} & 2 & 3 & 4 & 5 & 6 & 7 & 8 & 9 \\
\hline & $\begin{array}{l}\text { The number of } \\
\text { training samples }\end{array}$ & 10 & 20 & 30 & 40 & $\begin{array}{c}20 \\
10\end{array}$ & $\begin{array}{l}30 \\
20 \\
10\end{array}$ & $\begin{array}{l}40, \\
30, \\
20 \\
10\end{array}$ \\
\hline \multirow{4}{*}{ Poisson distribution } & 1000 & 0 & 0 & 0 & 0 & 0 & 0 & 0 \\
\hline & 10000 & 11 & 3 & 3 & 3 & 16 & 26 & 28 \\
\hline & 20000 & 15 & 16 & 19 & 15 & 23 & 30 & 33 \\
\hline & 30000 & 20 & 19 & 14 & 19 & 33 & 29 & 32 \\
\hline \multirow{4}{*}{ Normal distribution } & 1000 & 0 & 0 & 0 & 0 & 0 & 0 & 0 \\
\hline & 10000 & 0 & 0 & 0 & 0 & 0 & 0 & 0 \\
\hline & 20000 & 33 & 20 & 53 & 32 & 98 & 99 & 97 \\
\hline & 30000 & 60 & 68 & 84 & 83 & 97 & 97 & 97 \\
\hline
\end{tabular}




\begin{tabular}{|c|c|c|c|c|c|c|c|c|}
\hline \multirow{4}{*}{ Weibull distribution } & 2 & 3 & 4 & 5 & 6 & 7 & 8 & 9 \\
\hline & 1000 & 0 & 0 & 0 & 0 & 0 & 0 & 0 \\
\cline { 2 - 8 } & 10000 & 5 & 5 & 5 & 5 & 6 & 5 & 8 \\
\cline { 2 - 8 } & 20000 & 5 & 5 & 5 & 5 & 6 & 5 & 8 \\
\hline \multirow{4}{*}{ Pareto distribution } & 30000 & 6 & 6 & 5 & 6 & 5 & 6 & 7 \\
\cline { 2 - 8 } & 1000 & 0 & 0 & 0 & 0 & 0 & 0 & 0 \\
\cline { 2 - 8 } & 10000 & 0 & 0 & 0 & 0 & 0 & 0 & 0 \\
\cline { 2 - 8 } & 20000 & 15 & 9 & 20 & 10 & 15 & 49 & 41 \\
\hline
\end{tabular}

The neurons in the layers were interconnected according to the principle of «each with each». All connections of two neurons were assigned a weight coefficient, which was then corrected by the network during training. In hidden layers, the sigmoidal activation function was used, and in the output layer, the softmax activation function was used. The training sequence was formed from 30 thousand vectors of each of the distributions. The values for them were calculated on an argument taken randomly from the interval [0: 3000].

Table 2

The number of input samples successfully recognized by the neural network, \%

\begin{tabular}{|c|c|c|c|c|c|c|c|c|}
\hline & \multicolumn{7}{|c|}{ Number of hidden layers } \\
\hline & & \multicolumn{4}{|c|}{1} & 2 & 3 & 4 \\
\hline & & \multicolumn{7}{|c|}{ The number of neurons in the hidden layer } \\
\hline & $\begin{array}{l}\text { The number of } \\
\text { training samples }\end{array}$ & 10 & 20 & 30 & 40 & $\begin{array}{l}20 \\
10\end{array}$ & $\begin{array}{l}30, \\
20, \\
10\end{array}$ & $\begin{array}{c}40, \\
30, \\
20, \\
10\end{array}$ \\
\hline \multirow{4}{*}{$\begin{array}{l}\text { Hyperexpo-nential } \\
\text { distribution }\end{array}$} & 1000 & 56 & 55 & 55 & 55 & 55 & 58 & 56 \\
\hline & 10000 & 54 & 58 & 53 & 53 & 57 & 63 & 62 \\
\hline & 20000 & 65 & 62 & 62 & 41 & 52 & 62 & 60 \\
\hline & 30000 & 53 & 65 & 57 & 60 & 63 & 60 & 63 \\
\hline
\end{tabular}

During the study, it was found that an increase in the hidden layers or neurons in them leads to an increase in the recognition quality of not all distributions [15]. However, an increase in the training sample significantly increases the likelihood of correct recognition of some distributions supplied to the input of the neural network.

Based on the above experiments, the following neural network architecture was chosen: 51 neurons in the input layer, two hidden layers with 20 and 10 neurons, one output layer with five neurons (Fig. 2).

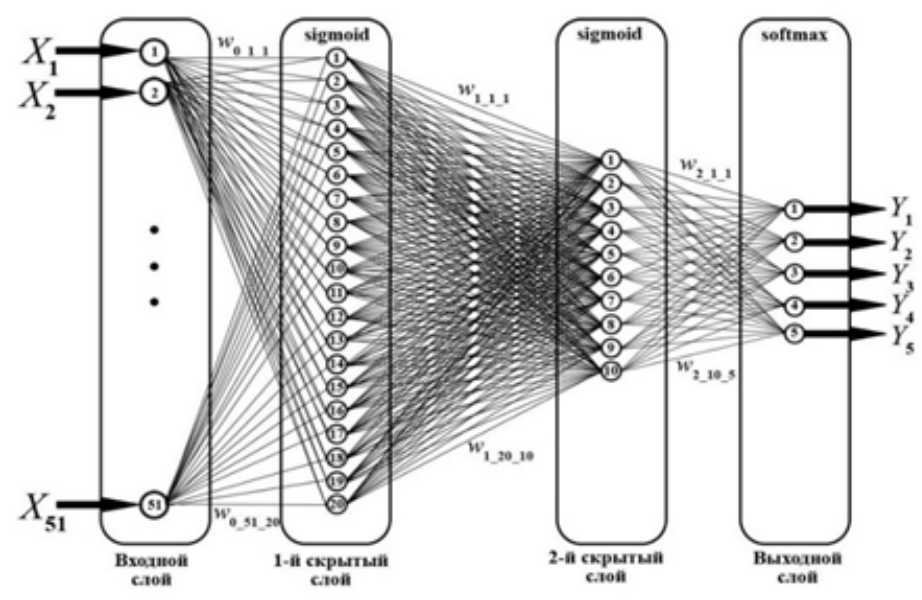

Figure 2. Architecture of the studied neural network 


\section{Training Sample Adjustment}

It was found that a neural network constructed and trained in the presented way cannot accurately recognize all types of distributions. The values of many of the studied distributions are mainly contained in the interval [0: 300] and have a long «tail» of significantly lower values. With a uniform choice of $\mathrm{x}$ from the domain of definition of values characteristic of each distribution, it turned out insufficiently, as a result of which the neural network could not reveal the distinctive features of all [16]. As a result, the training sample was formed in such a way that a larger number of $\mathrm{x}$ values were concentrated on the interval [0: 300], near the mode of the corresponding distribution, and the remaining one was evenly distributed outside it randomly.

Table 3 presents the results of testing a neural network when vectors of constructed distributions that were not included in the training set were fed to it. For each distribution, 100 experiments were performed. In each experiment, the correspondence of the value of the output vector was determined, which determined the distribution law recognized by the network and the given distribution law of the input sample applied to the input of the neural network. According to the results of all experiments, the proportion of successful tests was determined [17].

Table 3

The number of input samples successfully recognized by the neural network, \%

\begin{tabular}{|l|c|c|c|c|}
\hline \multirow{2}{*}{ Distribution } & \multicolumn{4}{|c|}{ Number of training sequences } \\
\cline { 2 - 5 } & 30000 & 50000 & 70000 & 100000 \\
\hline Poisson distribution & 76 & 84 & 78 & 81 \\
\hline Normal distribution & 100 & 100 & 100 & 99 \\
\hline Weibull distribution & 94 & 92 & 93 & 93 \\
\hline Pareto distribution & 99 & 99 & 99 & 99 \\
\hline Hyperexponential distribution & 100 & 100 & 100 & 100 \\
\hline
\end{tabular}

From Table 3 it follows that the network recognizes the normal distribution, Pareto distribution and hyperexponential distribution as follows. The probability of successful recognition for the normal distribution is about 0.97, for the Pareto distribution - 0.99 and for the hyperexponential distribution - 0.99.

It is important that, compared with the results shown in Tables 1 and 2, the share of recognized Poisson and Weibull distributions significantly increased. Consequently, the hypothesis of the necessity (in the formation of training samples) of the prevailing use of argument values gravitating to the mode value of the corresponding distributions is confirmed.

\section{Conclusion}

The obtained results prove the possibility of creating a neural network that can solve the problem of assigning the distributions of the values of the parameters of real traffic to one of the known probabilistic distributions

Thus, it was found that a network with 2 hidden layers, 20 neurons in the first hidden layer and 10 neurons in the second hidden layer will be sufficient architecture for recognizing the given distributions. In hidden layers, the sigmoidal activation function was used, and in the output layer, the Softmax activation function was used.

It was also revealed that an increase in the hidden layers or neurons in them leads to an increase in the recognition quality of not all distributions. However, an increase in the training sample significantly increases the likelihood of correct recognition of the distributions supplied to the input of the neural network.

When testing a neural network, it was noted that the quality of recognition of distributions by a neural network is affected not only by the size of the training sample, but also by its composition. In the course of the experiment, the hypothesis was confirmed that with a uniform choice of $\mathrm{x}$ from the domain of definition of values characteristic of each distribution, the neural network could not reveal the distinctive features of all. Correction of the training sample so that a larger number of $\mathrm{x}$ values are concentrated near the mode of the corresponding distribution, and the remaining one is evenly distributed outside it randomly, thereby increasing the stability of correct recognition.

Based on the results of the analysis of models of neural networks, and also taking into account the fact that the data processed during the analysis of teletraffic, firstly, do not have a very high dimension, secondly, the input vector fully describes the process under study, and thirdly, the main predicted task of the proposed 
analysis is a classification - it should be concluded that the preferred use in further studies of multilayer neural networks with direct signal propagation.

\section{References}

1 Гойхман В.Ю. Исследование вероятностных характеристик трафика при помощи аппарата нейронных сетей / В.Ю. Гойхман, А.И. Лапий. - М.: Электросвязь, 2018. - № 4. - С. 64-67.

2 Авраменко М.В. Выбор дисциплины передачи данных сенсорного узла / М.В. Авраменко, В.Ю. Гойхман. - М.: Первая миля, 2017. - № 2. - С. 34-39.

3 Гойхман В.Ю. Решение задачи классификации трафика с использованием нейронной сети / В.Ю. Гойхман, А.И. Лапий // Тр. учебных заведений связи. - 2016. - Т. 2, № 1. - С. 43-47.

4 Поздняк И.С. Исследование сетевого трафика на степень самоподобия / И.С. Поздняк, М.А. Буранова. - Самара: ИУНЛ ПГУТИ, 2013. - 8 с.

5 Степанов С.Н. Основы телетрафика мультисервисных сетей / С.Н. Степанов. - М.: Эко-Трендз, 2010. - $392 \mathrm{c}$.

6 Ложковский А.Г. Модель трафика в мультисервисных сетях с коммутацией пакетов / А.Г. Ложковский. - Наукові праці ОНАЗ ім. О.С. Попова. - 2010. - 40 с.

7 Авраменко М.В. Выбор дисциплины передачи данных сенсорного узла / М.В. Авраменко, В.Ю. Гойхман // Первая миля. - № 2. - 2017. - С. 34-39.

8 Гойхман В.Ю. Анализ трафика студенческого общежития / В.Ю. Гойхман, Т.Ю. Лушникова, Ю.А. Зиненко // Вестн. кибернетики. - 2016. - № 1 (21).

9 Вардзинский Р.Н. Справочник по вероятностным распределениям / Р.Н. Вардзинский. - СПб.: Наука, 2001. - 295 с.

10 Шелухин О.И. Самоподобие и фракталы: телекоммуникационные приложения / О.И. Шелухин, А.В. Осин, С.М. Смольский. - М.: Физматлит, 2008. - 368 с.

11 Goykhman V. Research of Typical Information Objects Traffic / V. Goykhman, L. Korganbaeva, A. Ermakov, M. Nikolaeva // Advances in Science and Technology Research Journal. - 2019. - Vol. 13, Issue 2. - P. 51-55.

12 Goikhman V. Evaluating the packet traffic parameter measurements / V. Goikhman, Sh. Seilov, N. Sokolov, L. Korganbayeva // Telecommunications and Radio Engineering. - 2019. - No. 78(6). - P. 489-499.

13 Christopher M. Bishop. Neural Networks for Pattern Recognition / Christopher M. Bishop. - New York: Oxford University Press, 1995. - 498 p.

14 Ciresan D. Multicolumn Deep Neural Network for Traffic Sign Classification / D. Ciresan, U. Meier, J. Masci, J.Schmidhuber // Neural Networks. - August 2012. - Vol. 34. - P. 333-338.

15 Hinton G. Deep Neural Networks for Acoustic Modeling in Speech Recognition / G. Hinton, L. Deng, D. Yu, G. Dahl, A. Mohamed, N. Jaitly, A. Senior, V. Vanhoucke, P. Nguyen, T. Sainath, B. Kingsbury // IEEE Signal Processing Magazine. - 2012. - Vol. 29, No. 6. - P. 82-97.

16 Каллан Р. Основные концепции нейронных сетей / Р. Каллан. - М.: Изд. дом «Вильямс», 2001. $287 \mathrm{c}$.

17 Башарин Г.П. Управление качеством и вероятностные модели функционирования сетей связи следующего поколения / Г.П. Башарин, Ю.В. Гайдамака, К.Е. Самуйлов, Н.В. Яркина. - М.: РУДН, 2008. -157 c. 


\title{
Ш. Сеилов, В. Гойхман, М. Касенова, А. Сейлов, Д. Шингисов \\ Инфокоммуникациялық трафикті талдау үшін нейрондық желінің модельдерін жасау
}

\begin{abstract}
Мақалада IP пакеттер жиынтығы ретінде ұсынылған, трафиктің барлық түріне қызмет көрсететін мультисервистік желілер болып табылатын қазіргі инфокоммуникациялық желілердің мәселелері қарастырылды. Телекоммуникациялық желілер жиынтығы үшін осы трафиктің сипаттамалары талданды, олардың әрқайсысы белгілі бір қызмет түріне бағытталған. Трафикті зерттеу нәтижесінде алынған білім телекоммуникация саласының әртүрлі салаларында қабылданатын шешімдердің тиімділігін арттырудың маңызды факторы болып табылады. Желідегі трафиктің сипаты мен оның заңдылықтарын білу қажеттілігі анықталды және дәлелденді. Онсыз желілерді тиімді басқару, оларды дамыту үшін шешімдер әзірлеу, желінің қауіпсіздігін қамтамасыз ету және қажетті сапа деңгейін ұстап тұру мүмкін емес. Мультисервистік желілерді салу бойынша жұмыстардың көптігіне қарамастан, бірқатар мәселелер қосымша зерттеуді қажет етеді. Заманауи конвергентті трафикті, мультисервистік желілерді зерттеу нәтижесінде олардың сипаттамаларының жоғары өзгергіштігін ескерсек, оның табиғаты туралы білмейтінімізді көрсетті. Қазіргі желілердің трафигіне кездейсоқ факторлардың көптігі әсер етеді, бұл оның сипаттамаларын детерминант ретінде талдау мүмкіндігін жоққа шығарады. Осылайша, зерттелетін трафиктің параметрлері статистикалық, ықтималды сипатта болатынын айтуға болады және уақыт өте келе кездейсоқ өзгеруі мүмкін, сондықтан зерттеу негізінде автор статистикалық талдау әдістерін қолдана отырып зерттеу жүргізуді ұсынады. Трафикті зерттеу үшін ықтималдықтар теориясы мен математикалық статистика құралдарын пайдалану керек.
\end{abstract}

Kiлm сөздер: инфокоммуникациялық желілер, нейрондық желілер, мультисервистік трафик, трафиктің ықтималды сипаттамалары, трафиктің математикалық модельдері, мультимедиялық қызметтер, мультисервистік трафик, нейрондық технологиялар, зерттелген таратулар, трафиктің жіктелімдері, ақпараттық объектілер.

\author{
Ш. Сеилов, В. Гойхман, М. Касенова, А. Сейлов, Д. Шингисов
}

\section{Разработка моделей нейронных сетей для анализа инфокоммуникационного трафика}

В статье рассмотрены проблемы сегодняшних инфокоммуникационных сетей, основу которых составляют мультисервисные сети, обслуживающие трафик всех видов, представленный в виде совокупности IP-пакетов. Проанализированы характерные особенности этого трафика для набора сетей телекоммуникаций, каждая из которых ориентирована на определенный класс услуг. Знания, полученные в результате проводимых исследований трафика, являются существенным фактором для повышения действенности принимаемых решений в самых различных областях телекоммуникационной отрасли. Выявлена и обоснована необходимость знания природы циркулирующего в сети трафика и законов его поведения. Без этого невозможно эффективное управление сетями, выработка решений по их развитию, обеспечение сетевой безопасности и поддержка необходимого уровня качества. Несмотря на большое число работ о построении мультисервисных сетей, ряд вопросов требует дальнейшего изучения. Анализ исследований трафика современных конвергентных, мультисервисных сетей показал недостаточность имеющихся знаний о его природе и законах поведения, учитывая высокую изменчивость его характеристик. Трафик современных сетей подвержен влиянию большого количества случайных факторов, что исключает возможность анализа его характеристик как детерминированных. Таким образом, можно утверждать, что параметры исследуемого трафика носят статистический, вероятностный характер, могут изменяться в течение времени случайным образом, и, соответственно, на основе проведенного исследования авторами предложено исследование с использованием статистических методов анализа. Для изучения трафика следует использовать инструменты теории вероятностей и математической статистики.

Ключевые слова: инфокоммуникационные сети, нейронные сети, мультисервисный трафик, вероятностые характеристики трафика, математические модели трафика, мультимедийные услуги, мультисервисный трафик, нейросетевые технологии, исследуемые распределения, классификации трафика, информационные объекты. 


\section{References}

1 Goikhman, V.Yu. (2018). Issledovanie veroiatnostnykh kharakteristik trafika pri pomoshchi apparata neironnykh setei [Study of probabilistic characteristics of traffic using the apparatus of neural networks]. Moscow: Elektrosviaz [in Russian].

2 Avramenko, M.V., \& Goikhman, V.Yu. (2017). Vybor distsipliny peredachi dannykh sensornoho uzla [Select the data transfer discipline of the sensor node]. Pervaia milia - First mile, 2, 34-39 [in Russian].

3 Goikhman, V.Yu. (2016). Reshenie zadachi klassifikatsii trafika s ispolzovaniem neironnoi seti [Solution of the problem of traffic classification using a neural network]. Trudy uchebnykh zavedenii sviazi, Vol. 2, 1, 43-47 [in Russian].

4 Pozdniak, I.S. (2013). Issledovanie setevoho trafika na stepen samopodobiia [Study of network traffic on the degree of self-similarity]. Samara: IUNL PGUTI [in Russian].

5 Stepanov, S.N. (2010). Osnovy teletrafika multiservisnykh setei [Fundamentals of teletraphy of multiservice networks]. Moscow: Eko-Trendz [in Russian].

6 Lozhkovskii, A.G. (2010). Model trafika v multiservisnykh setiakh s kommutatsiei paketov [Traffic model in multiservice networks with packet switching]. Naukovi pratsi ONAZ imeni O.S. Popova [in Russian].

7 Avramenko, M.V., \& Goikhman, V.Yu (2017). Vybor distsipliny peredachi dannykh sensornoho uzla [The choice of discipline of data transmission of the sensor node]. Pervaia milia - First mile, 2, 34-39 [in Russian].

8 Goikhman, V.Yu., Lushnikova, T. Yu., \& Zinenko, Yu.A. (2016). Analiz trafika studencheskoho obshchezhitiia [Traffic Analysis of student hostel]. Vestnik kibernetiki, 1 (21) [in Russian].

9 Vardzinskii, R.N. (2001). Spravochnik po veroiatnostnym raspredeleniiam /The reference probability distributions]. Saint Petersburg: Nauka [in Russian].

10 Shelukhin, O.I. (2008). Samopodobie i fraktaly: telekommunikatsionnye prilozheniia [Self-Similarity and fractals: telecommunication applications]. Moscow: Fizmatlit [in Russian].

11 Goykhman, V., Korganbaeva, L., Ermakov, A., \& Nikolaeva, M. (2019). Research of Typical Information Objects Traffic. Advances in Science and Technology Research Journal, Vol. 13, Issue 2, 51-55.

12 Goikhman, V., Seilov, Sh., Sokolov, N., \& Korganbayeva, L. (2019). Evaluating the packet traffic parameter measurements. Telecommunications and Radio Engineering, 78 (6), 489-499.

13 Christopher, M. Bishop. (1995). Neural Networks for Pattern Recognition. New York: Oxford University Press.

14 Ciresan, D., Meier, U., Masci, J. \& Schmidhuber, J. (2012). Multicolumn Deep Neural Network for Traffic Sign Classification. Neural Networks, Vol. 34, 333-338.

15 Hinton, G., Deng, L., Yu, D., Dahl, G., Mohamed, A., \& Jaitly, N. et al. (2012). Deep Neural Networks for Acoustic Modeling in Speech Recognition. IEEE Signal Processing Magazine, Vol. 29, 6, 82-97.

16 Kallan, R. (2001). Osnovnye kontseptsii neironnykh setei [Basic concepts of neural networks]. Moscow: Izdatelskii dom «Wiliams» [in Russian].

17 Basharin, G.P. (2008) Upravlenie kachestvom i veroiatnostnye modeli funktsionirovaniia setei sviazi sleduiushcheho pokoleniia [Quality management and probabilistic models of functioning of communication networks of the next generation]. Moscow: RUDN [in Russian]. 